
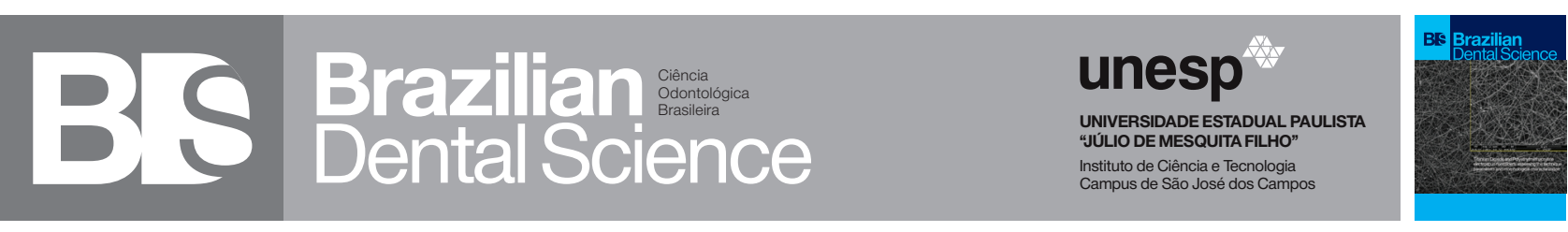

\title{
Stress distribution and failure load of multilayer and monolayer glass ceramic
}

Distribuição de tensão e carga para fratura de cerâmica vítrea em multicamada e em monocamada

Karen Cristina ARCHANGELO ${ }^{1}$, Marcela Moreira PENTEADO ${ }^{1}$, Amanda Maria de Oliveira DAL PIVA ${ }^{1}$, Andrea Souza NOGUEIRA ${ }^{1}$, João Paulo Mendes TRIBST ${ }^{1}$, Alexandre Luiz Souto BORGES ${ }^{1}$

1 - São Paulo State University (Unesp) - Institute of Science and Technology, São José dos Campos - Department of Dental Materials and Prosthodontics - São José dos campos - SP - Brazil.

\begin{abstract}
This short report evaluated the differences in stress concentration and the load to fracture of multilayered and monolayer glass ceramic discs. Using a simulated static structural analysis, the 3D model of the samples received a load of $150 \mathrm{~N}$ and results in maximum principal stress were obtained. For the in vitro analysis, the samples ( $\varnothing 12 \mathrm{~mm}$ ) were submitted to a compressive test (100 kgf, $1 \mathrm{~mm} / \mathrm{min}$ ). The data was analyzed using one-way analysis of variance and Tukey test ( $\alpha=5 \%$ ). The monolayer group showed a lower stress peak (129.24 MPa) and higher load to fracture $(118.38 \mathrm{~N})$ than the multilayered group with 211.04MPa and $48.34 \mathrm{~N}$, respectively. All samples presented catastrophic failure with its origin on the tensile surface. Therefore, the monolayer ceramic group showed superior mechanical behavior than the multilayered group.
\end{abstract}

\section{KEYWORDS}

Ceramics; Monoblock restoration; Finite element analysis.

\section{RESUMO}

Este relato avaliou a diferença na concentração de tensão e a carga para fratura de discos de cerâmica vítrea em multicamada e monocamada. Usando uma análise estática estrutural simulada, o modelo 3D das amostras recebeu uma carga de $150 \mathrm{~N}$ e resultados de tensão máxima principal foram obtidos. Para a análise in vitro, as amostras ( $\varnothing 12 \mathrm{~mm}$ ) foram submetidas a um teste de compressão (100 kgf, $1 \mathrm{~mm} / \mathrm{min}$ ). Os dados foram analisados por análise de variância e teste de Tukey ( $\alpha=5 \%$ ). O grupo em monocamada mostrou um menor pico de tensão $(129,24 \mathrm{MPa})$ e maior carga para fratura $(118,38 \mathrm{~N})$ do que o grupo multicamada com 211,04 MPa e 48,34 N, respectivamente. Todas as amostras apresentaram falha catastrófica com sua origem na superfície de tração. Portanto, o grupo em monocamada apresentou comportamento mecânico superior ao grupo multicamadas.

\section{PALAVRAS-CHAVE}

Cerâmica; Restauração monobloco; Análise de elementos finitos.

\section{INTRODUCTION}

$\mathrm{D}$ ental ceramics are widely used in restorative treatments due to their excellent aesthetics, biocompatibility, and compressive strength[1]. Despite all the advances in ceramic material, the effects of tensile forces on restorations in function, especially in the posterior region [2-5], generate undesirable effects such as micro-cracks, delamination or catastrophic fractures due to the ceramic characteristic structures[6].

Some authors define that the multilayer arrangement provides early failure due to the incompatibility of materials with different mechanical properties [4]. Moreover, it is reported 
that, for multilayers design, the presence of a cement layer is responsible for absorbing part of the stress generated during loading [3] and reduces internal residual stress of polycrystalline ceramic system [4]. Thus, there is no data in the literature showing the biomechanical effect of a multilayer design of one glass ceramic system.

Among different methodologies used in dental material studies, finite element analysis (FEA) consists in a reliable mathematic method to analyze complex mechanical behavior conditions. This mathematical tool shows harmful stress concentration areas and the most probable points of failure[3]. However, in vitro complementary analyzes are recommended to consolidate the results [5]. The present study aimed to evaluate the stress distribution on ceramic discs arranged in monolayer and multilayers by FEA, and evaluate the fracture load of this ceramic design. The alternative hypothesis was that neither biaxial flexural strength nor stress distribution would be influenced by the ceramic design.

\section{MATERIALS AND METHODS}

\section{Finite element analysis}

A tridimensional (3D) model of a disc with $12 \mathrm{~mm}$ in diameter was generated using modeling software (CAD Rhinoceros 4.0, McNeel North America, Seattle, WA, USA) - monolayer group design. Then, the multilayered design group was modeled with three cemented discs $(0.3 \mathrm{~mm}$ thickness), totaling $1.2 \mathrm{~mm}$ of thickness. Next, the geometries were imported to the analysis software (CAE ANSYS 17.2, ANSYS Inc., Houston, TX, USA) in STEP format and the mesh was composed by tetrahedral elements. A convergence test of mesh was performed before the analysis. The ceramic elastic modulus $[(\mathrm{E})=48.7]$ and Poisson ratio $[(\mathrm{v})=0.23]$ were based on the literature [7]. The materials were considered isotropic, homogeneous, linear and elastic. A static load $(150 \mathrm{~N})$ was applied to the middle of the discs with a contact area of $2 \mathrm{~mm}$ diameter. The system fixation was simulated by three-balls of industrial steel (Figure 1) and all contacts were considered perfectly bonded. Finally, maximum principal stress $(\mathrm{MPa})$ results were requested.

\section{Sample fabrication}

Feldspathic ceramic blocks (39 mm x 19 mm x 15.5 mm - Vita Mark II, Zahnfabrik, Bad Säckingen, Germany) were rounded in an automatic orbital sander (Buehler, Ecomet 250, Illinois, EUA) using sandpapers with grain size \#600. Next, the rollers were cut using a precision cutting machine (Isomet 1000, Buehler, Illinois, EUA). Then, all discs were polished (\#400 to $\# 1200$ ) to standardized the final thickness of $0.3 \mathrm{~mm}(\mathrm{n}=30)$ and $1.2 \mathrm{~mm}(\mathrm{n}=10)$, as measured by a digital caliper (Mitutoyo Corporation, Tokyo, Japan). The discs were cleaned with isopropyl alcohol in an ultrasonic bath (Cristófoli Equipamentos de Biossegurança LTDA, Paraná, Brazil) for 5 min and dried with an air jet.

For the multilayered group, the disc surfaces were conditioned with hydrofluoric acid (Dentsply, Catanduva, São Paulo, Brazil) for 60 seconds, than washed for 60 seconds and dried. Next, silane was applied (Monobond Plus, Ivoclar Vivadent, Schaan, Liechtenstein) and 60 seconds were waited for solvent evaporation. Then, the resin cement (Multilink $\mathrm{N}$, Ivoclar Vivadent, Schaan, Liechtenstein) was applied between adhesive discs surfaces. Sample thicknesses were assessed by a digital micrometer (serie 369, Mitutoyo, Tokyo, Japan). Photopolymerization was performed for 20 seconds (1200 mW / cm2 - Radii Cal, SDI, Australia).

\section{Mechanical test}

The samples were subjected to a universal testing machine (Emic, DL1000, EMIC, São José dos Pinhais, Brazil) and three balls of $3.2 \mathrm{~mm}$ of diameter were centralized, $10 \mathrm{~mm}$ equidistant between the middle (Figure 1). The load was applied using a $2.0 \mathrm{~mm}$ diameter steel indenter. A load cell of $100 \mathrm{kgf}$ was used at a speed of $1 \mathrm{~mm} / \mathrm{min}$ with room temperature at $23 \pm 1$ ${ }^{\circ} \mathrm{C}$ until fracture. The mean load to fracture (in Newton) and the number of fragments were tabulated. 


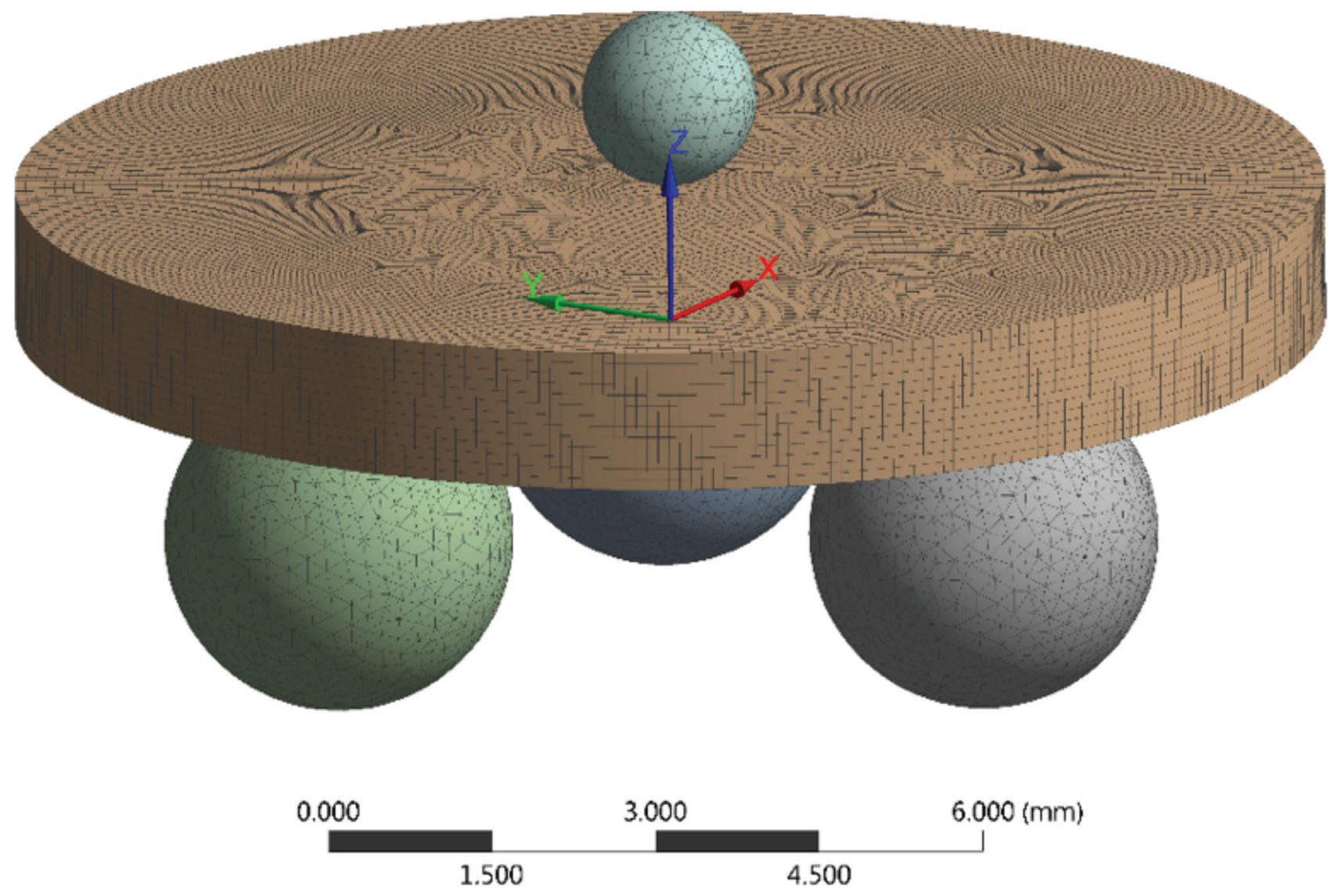

Figure 1 - Glass ceramic discs modeled according to the in vitro test and meshed with tetrahedral elements.

\section{Failure analysis}

All samples were analyzed in a stereomicroscope (STEMI2000-C, Carl Zeiss do Brasil Ltda., Rio de Janeiro, Brazil) using the transillumination technique. Two representative fractured samples were inspected using scanning electron microscopy (Inspect S50, FEI, Czech Republic). The samples were sputter coated with gold for 130 seconds at $15 \mathrm{~mA}$, creating a 30-nm-thick layer and examined under different standard SEM magnifications operated at $20 \mathrm{KV}$ using secondary electron detection by a single operator.

\section{Data analysis}

The results from FEA were summarized in colorimetric graphs and evaluated qualitatively. The load to failure data was analyzed by descriptive statistics, one-way analysis of variance and Tukey test and the number of fragments was analyzed by Pearson correlation. All tests had 5\% significance.

\section{RESULTS}

For FEA, maximum principal stress map (Figure 2) showed that the multilayered design presented higher stress concentration (211.04 $\mathrm{MPa})$ than the monolayer design (129.24 MPa). For in vitro test, the monolayer group showed higher mean load to failure value (118.38 \pm $10.83)^{\mathrm{A}}$ than the multilayered group (48.34 \pm $23.76)^{B}$. No correlation was found between the number of fragments and the failure load of the tested samples $\left(r^{2}=0.14\right)$. Photomicrography (Figure 3) showed the tensile surface of the samples as the fracture origin site for both tested groups, corroborating with the stress concentration sites indicated by FEA. 

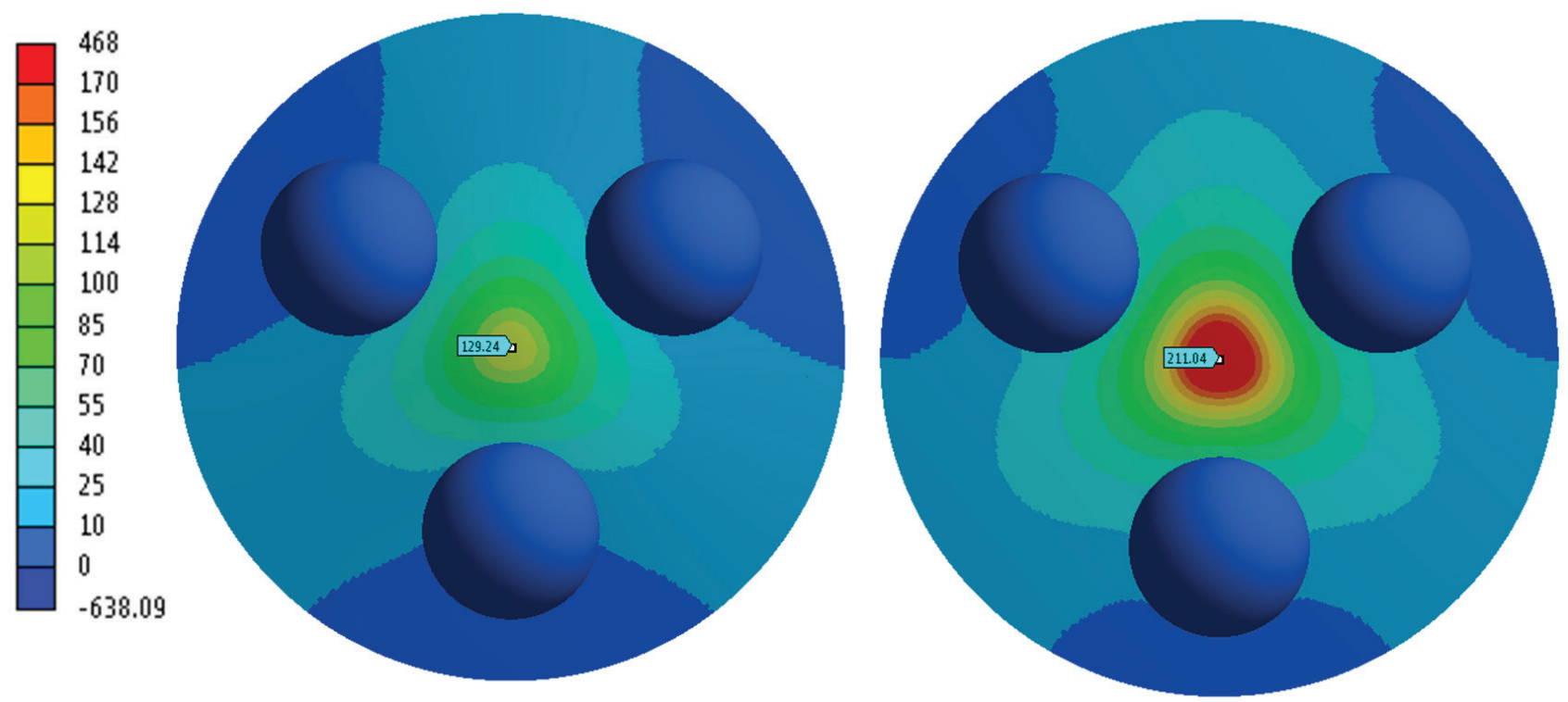

Figure 2 - Maximum principal stress results in the ceramic discs: (a) Monolayer; (b) Multilayered.
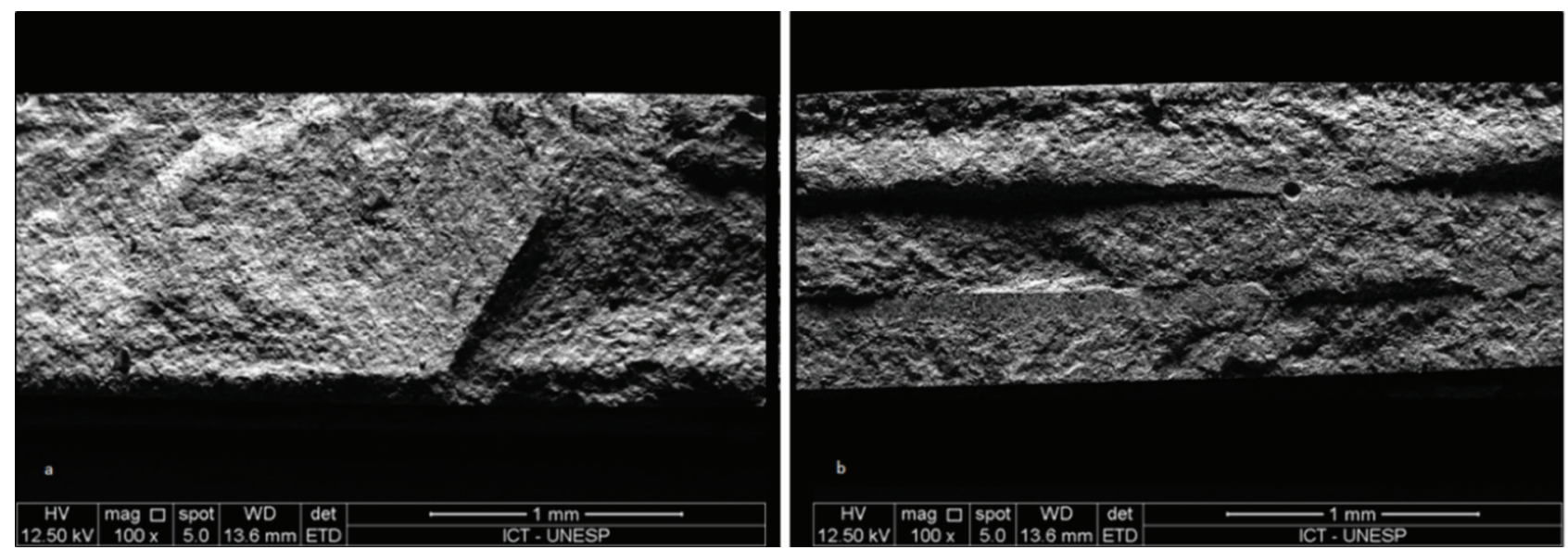

Figure 3 - Scanning electron micrography of fractured discs to detect the failure origin: (a) Monolayer; (b) Multilayered.

\section{DISCUSSION}

Several strategies such as modifying the infrastructure shape, sintering temperatures or the cementing agent have already been proposed with the aim of reducing the occurrence of crack propagation, chipping and catastrophic failures $[8,9]$. The studies that point out these followups are inconclusive, since they do not measure exactly when the failure occurred $[9,10]$. There is a tendency to use techniques that reduce the need for manual labor such as CAD/CAM facility for infrastructures and monolithic restoration manufacturing [10-12]. Another way to minimize the stress concentration in ceramic crowns is to manufacture them in a multilayered design [13]. However, the monolithic arrangement of a feldspathic ceramic herein was mechanically superior, and therefore the hypothesis of this study was rejected.

Similar findings were found when comparing monolayer and bilayer zirconia crowns which $1.5 \mathrm{~mm}$ thick, where the bilayer group showed the lowest flexural strength in comparison with monolayer samples [13]. 
In multilayer crowns, tensile stress usually occurs due to the thermal-mechanical mismatch between the different ceramics [14]. Also, prior to select the layers it is necessary to consider the thermal expansion coefficient in order to reduce the residual tensile stresses [11]. It is possible to predict the residual tensile stress through mathematical formulae relating the overlap of thermal stress and the compressive stress simulated by FEA [15].

As failure analyses demonstrated that there is no correlation for the number of fragments and the discs load to failure, it cannot be concluded that the material's behavior only depends on the applied load, but also on the ceramic design. Although previous studies have shown that resin cement completes the superficial defects, which can improve the ceramic strength, [16] this benefit was not evidenced herein.

FEA results suggest that the multilayered discs would fail at lower load values than the monolithic discs due to higher stress concentration. This result was verified during the in vitro test with the multilayer group presenting $60 \%$ lower value for load to failure compared to the monolithic group. Due to cement layer thickness and polymerization shrinkage being factors that can interfere in the stress concentration $[11,15]$, it is possible to suppose that these factors could be responsible for catastrophic failures, instead of absorbing stress and distributing it in minor proportions to the ceramic [16].

On the other hand, the use of monolithic ceramics allows for high facility during the manufacturing process of prostheses $[9,16,17]$, in addition to higher mechanical strength. Studies with zirconia monolithic crowns or lithium disilicate demonstrated a restoration survival ratio higher than $90 \%$ after 5 years. [2,10] Dhima et al. [17] compared bilayer and monolithic crowns and concluded that monolayer design for crowns were more viable for posterior teeth. Zhang et al. [15] also showed that zirconia and lithium disilicate monolithic crowns are able to withstand masticatory forces.

The limitations of this short communication consist in using homogeneous geometries, which absence of internal defects, and no simulation of factors present in the oral cavity such as temperature, $\mathrm{pH}$ variation, biofilm or mechanical fatigue. These limitations do not invalidate the results, but suggest that they should be carefully evaluated and used to complement other papers [18].

\section{CONCLUSION}

Within the limitations of this study, it can be concluded that: at the same thickness, the monolayer glass ceramic design is less susceptible to failures than multilayered restorations, showing less stress concentration and higher fracture load.

\section{REFERENCES}

1. Tinschert J, Zwez D, Marx R, Anusavice KJ. Structural reliability of alumina, feldspathic, leucite, mica and zirconia based ceramics. J Dent. 2000; 28(7):529-35.

2. Pjetursson BE, Sailer I, Zwahlen M, Hämmerle CH. A systematatic review of the survival and complication rates of ceramic and metalceramic reconstructions after na observation period of at least 3 years, part I: single crowns. Clin Oral Implants Res. 2007 Jun;18 Suppl 3:73-85.

3. Dal Piva AM0, Tribst JPM, Borges ALS, Souza ROAE, Bottino MA. CAD-FEA modeling and analysis of different full crown monolithic restorations. Dent Mater. 2018 Sep;34(9):1342-1350. doi: 10.1016/j. dental.2018.06.024. Epub 2018 Jun 20.

4. Costa AK, Borges AL, Fleming GJ, Addison 0. The strength of sintered and adhesively bonded zirconia/veneer-ceramic bilayers. J Dent 2014:42:1269-76.

5. Tribst JPM, Dal Piva AM, Rodrigues VA, Borges ALS, Nishioka RS. Stress and strain distributions on short implants with two different prosthetic connections: an in vitro and in silico analysis. Braz Dent Sci. 2017;20(3):101-9.

6. Dua J, Niuc X, Soboyejoa W. Creep-assisted slow crack growthin bio-inspired dental multilayers. J Mech Behav Biomed Mater. 2015 Jun;46:41-8. doi: 10.1016/j.jmbbm.2015.01.019. Epub 2015 Feb 3.

7. Quinn GD. Fractography of Ceramics and Glasses. Natl Inst Stand Technol. 2007; Spec Publication 960-16. doi: 10.6028/NIST.SP.960-16e2.

8. Dhima M1, Assad DA, Volz JE, An KN, Berglund LJ, Carr AB, Salinas TJ. Evaluation of fracture resistance in aqueous environment of four restorative systems for posterior applications. Part 1. J Prosthodont. 2013 Jun;22(4):256-60. doi: 10.1111/j.1532-849X.2012.00948.x. Epub 2012 Dec 20. 
9. Pieger S, Salman A, Bidra AS. Clinical outcomes of lithium disilicate single crowns and partial fixed dental prostheses: a systematic review. J Prosthet Dent. 2014 Jul;112(1):22-30. doi: 10.1016/j. prosdent.2014.01.005. Epub 2014 Mar 24.

10. Schmitter M, Mueller D, Rues S. Chipping behavior of all-ceramic crowns with zirconia framework and CAD/CAM manufactured veneer. J Dent. 2012 Feb;40(2):154-62. doi: 10.1016/j.jdent.2011.12.007. Epub 2011 Dec 14.

11. Lameira DP, Buarque e Silva WA, Andrade e Silva F, De Souza GM. Souza. Fracture strength of aged monolithic and bilayer zirconia-based crowns. Biomed Res Int. 2015;2015:418641. doi: 10.1155/2015/418641. Epub 2015 0ct 21.

12. Du J, Niu X, Rahbar N, Soboyejo W. Bio-inspired dental multilayers: effects of layer architecture on the contact-induced deformation. Acta Biomater. 2013 Feb;9(2):5273-9. doi: 10.1016/j.actbio.2012.08.034.

13. Hsueh CH, Luttrell CR, Becher PF. Analyses of multilayered dental ceramics subjected to biaxial flexure tests. Dent Mater. 2006 May;22(5):460-9. Epub 2005 Aug 11.
14. Fleming GJ1, Hooi P, Addison 0 . The influence of resin flexural modulus on the magnitude of ceramic strengthening. Dent Mater. 2012 Jul;28(7):769-76. doi: 10.1016/j.dental.2012.04.003.

15. Zhang Y, Mai Z, Barani A, Bush M, Lawn B. Fracture resistant monolithic dental crowns. Dent Mater. 2016 Mar;32(3):442-9. doi: 10.1016/j.dental.2015.12.010.

16. Gehrt M, Wolfart S, Rafai N, Reich S, Edelhoff D. Edelhoff. Clinical results of lithium-disilicate crowns after up to 9 years of servisse. Clin Oral Investig. 2013 Jan;17(1):275-84. doi: 10.1007/s00784-012-0700-x.

17. Dhima M, Paulusova V, Carr AB, Rieck KL, Lohse C, Salinas TJ. Practice based clinical evaluation of ceramic single crowns after at least five years. J Prosthet Dent. 2014 Feb;111(2):124-30. doi: 10.1016/j. prosdent.2013.06.015.

18. Datte CE, Tribst JP, Dal Piva AO, Nishioka RS, Bottino MA, Evangelhista AM, Monteiro FMM, Borges AL. Influence of different restorative materials on the stress distribution in dental implants. J Clin Exp Dent. 2018 May 1;10(5):e439-e444. doi: 10.4317/jced.54554.

\section{João Paulo Mendes Tribst}

(Corresponding address)

Instituto de Ciência e Tecnologia - Departamento de materiais dentários e prótese,

UNESP, São José dos Campos.

Avenida Eng. Francisco José Longo 777, Jardim São Dimas.

São José dos Campos, SP, Brasil.

CEP: 12245-000. Phone: +55-12 39479032, Fax: +55-12 39479010

Date submitted: 2018 Jun 27

Email: joao.tribst@unesp.br 